\title{
Instagram: The Alternative Media in Batik Promoting
}

\author{
Hanny Hafiar ${ }^{1}$, Priyo Subekti ${ }^{2}$, Kokom Komariah $^{3}$, Lukiati Komala $^{4}$, Susie Perbawasari ${ }^{5}$ \\ \{email:hanny.hafiar@unpad.ac.id; priyo.subekti@unpad.ac.id; kokom.komariah@unpad.ac.id; \\ susie.perbawasari@unpad.ac.id\} \\ 1,2,3,4,5 Universitas Padjadjaran, Bandung, Indonesia
}

\begin{abstract}
The management of promotional media by West Java Batik entrepreneur through the use of social media Instagram has not been done optimally. One indicator that can be seen is the number of West Java Batik hashtags, which are still fewer when compared to the number of batik hashtags originating from the provinces of Central Java and Yogyakarta. Therefore, the purpose of this study is to analyze a number of problems which are considered as the causes of the lack of optimal management of Instagram social media as a promotional media for West Javanese batik. The method used in this study is a descriptive case study which tries to describe the problem by observing the Instagram account of the West Java batik businessman. The results obtained indicate that there is a neglect of the functions and features available on the Instagram platform, so that information dissemination and product promotion activities cannot be carried out optimally. This is due to a lack of understanding and ability to optimize available features.
\end{abstract}

Keywords: Instagram, Digital Marketing, Batik, Communication Technology.

\section{Introduction}

The existence of the hashtag as one of the facilities provided by social media on various platforms has not been utilized by the West Java batik business optimally. This is due to a lack of awareness due to ignorance and also the limited skills in utilizing social media as a media campaign, whereas: Through the empowerment of small-scale industries, batik craftsmen are encouraged to have the ability to capture the dynamics of social reality behavior and economic realities related to the use of resources in the aspects of production, economic, social and ecological mechanisms [1].

Therefore, the existence of social media as part of the development of the times must also be studied carefully by batik businessmen in West Java. Moreover, the cultural value of West Java in the batik industry has not been as thick and as popular as batik from Yogyakarta and solos that have been strengthened by the existing social system. This refers to the statement that: Social systems in Yogyakarta and Solo affect the design of batik labels. The high cultural values of the Yogyakarta palace produce more formal and rigid typography used in batik labels, giving a classic taste. Meanwhile, the more urbanized cultural roots of Surakarta produce flowing typography and trendy casual flavors [2].

Another alternative that can be pursued to support the promotion and marketing activities of West Java batik is to collaborate with competitors, namely co-option, which has the opportunity to create synergies that can encourage the growth of small and medium industries 
[3]. Therefore, the West Java batik businessmen should start moving, synergizing, and performing to promote and market their products through various promotional media, including through the use of hashtags in their respective social media accounts, so that \#batikjawabarat virality can be one of the loopholes to popularize and position West Java batik as the host in the minds of the West Java people.

That is, in the millennial era like today, all fields of business inevitably have to adapt to the times. In today's technological era, awareness of the importance of the role of technology media must be studied and understood as a whole, because in the meantime, there are many companies that use digital marketing, it makes anyone who is unable to accompany the steps and take advantage of opportunities in digital marketing, must be prepared to be eliminated from business competition [4].

The utilization of social media is not optimal as a medium for promotion and marketing of West Java batik due to the unavailability of online media management staff in these companies. As a result, the lack of digital skills raises its own problems in marketing in online media [5]. This is understandable because to hire or employ an expert to manage online media for business needs requires its own funds. Even though most companies engaged in batik, are small and medium business institutions that still need support in developing their business. In contrast to the results of the following research which shows that: Digital marketing has been successfully used by an International Education Institute to improve its business practices. Therefore, any institution as a business institution can learn from positive cases and adopt a digital marketing mechanism that has been used by several successful companies and adjust it to the conditions of the company [6]. There is three information related to the hashtag, the factors covered are (1) the popularity of the hashtag; (2) hashtag textual information; and (3) the hashtag posting time factor [7]. Based on these matters, this study aims to analyze the appearance of the Instagram account of West Java Batik entrepreneur who carries out promotions through the Instagram platform.

\section{Method}

This study uses a descriptive case study method, by analyzing a number of Instagram accounts of batik businesses in West Java. The areas of entrepreneur observed are the entrepreneur in Bandung Raya area, which includes Bandung City, Cimahi, Bandung Regency, and West Bandung Regency. The reason for the selection of these regions was because these regions constituted areas which included in the provincial capital. By looking at many Instagram accounts from the West Java Batik business, three accounts can be identified from an entrepreneur who has a reputation based on product aspects. The analysis carried out covers aspects of the information presented, the appearance, and the interactions carried out by the entrepreneur with consumers, and prospective consumers. The data are collected by conducting observations and interviews with a number of representatives from business people, related to the management of social media used to promote West Java Batik products. In this study the social media that become the object of the research is Instagram. 


\section{Results and discussion}

Based on the results of analysis of a number of Instagram accounts from West Java Batik entrepreneur, a number of data showed that there were a number of things that needed to be improved in managing social media by batik entrepreneurs in West Java, in using the Instagram platform as a media for promotion and marketing of products and the brand. These factors include:

Table 1. Problems Identification in Using Instagram as a Promotional Media

\begin{tabular}{l} 
Identifiable problems \\
\hline The number of followers is relatively low \\
The content and packaging of the information posted is still not enough to capture the \\
attention of the target audience \\
There is no setting up of an account to become an account that can be accessed by the public \\
The low number of posts \\
Do not post regularly \\
The limited number of comments which commented on the post \\
It does not directly respond to potential customers who make comments \\
Not all photos posted are captioned \\
The lack of use of hashtags \\
Using an influencer or endorser brand that is not well known to the public \\
Photos posted do not have the quality and artistic value of photos \\
Posts are not thematic \\
Not yet using the quiz facility \\
Not yet using the Instastory voting facility \\
Not yet linked to other social media \\
There are still posting that are less relevant to business goals \\
Have not made the account an official account that has blue verification tags \\
Have not filled out the data in the bio business \\
Not yet utilizing impression management facilities
\end{tabular}

The number of followers in several accounts that promote and market West Java batik ranges from a figure that is still relatively far from the number of followers on similar accounts in Yogyakarta and Central Java. This shows that the use of social media is not optimal as a medium that can be used to disseminate information, whereas user-based social media or User-Made Content (UGC) provides easy access for users to disseminate information to the public. User-created content (UGC) offers the uniqueness that every user can become a marketer [8], including disseminating the existence of West Java batik. Furthermore, in addition to the hashtag, one of the uses of technology media that can be used to find information on how much the result of promotion and marketing efforts to popularize batik in West Java is Search Engine Optimize. In a number of accounts that promote and market the West Java Batik, the content and packaging of information posted, sometimes not enough to capture the attention of the target audience, therefore it is also necessary to understand and strategy to utilize the search engine optimization methods, and tags on multiple platforms. different [9]. There are times when business people are less careful and do typos so that they are not detected by SEO.

Another factor is that there is a mistake made by the account maker that aims to promote and market their business when they do not set up an account, becoming an account that can be accessed by the public. This causes a limited number of accesses who can see their 
promotional and marketing efforts; therefore, business people should be able to change the account settings from private to public, so that account usage can be done to pursue commercial objectives [10]. Another thing that can be observed is regarding the pattern of posting content. There are several business accounts that attempt to promote and market West Java batik that does not regularly make a profit so that the public who are the target consumers do not get new information about batik in West Java regularly. In fact, actually when business people post content regularly, present products and brands in an inspiring way, it will attract and increase awareness and target recognition of the brand [11].

Based on observation data, the number of comments commenting on posts made by business people on their Instagram accounts is still limited, so it can be seen that the management of social media by batik entrepreneurs in West Java is not optimal because the posts made by business people on social media as part from promotional media and marketing, it has not been able to lure followers to comment. Whereas companies can convert individual social media users, to become advertisers who give a positive impression on the product [12], meaning that the positive comments posted by followers in the form of comments showing positive interest or testimonials can actually improve the image and product and company reputation.

The section also shows the weakness of business people in capturing opportunities to improve reputation. Among comments from followers, there were questions that showed followers' interest or interest as potential buyers who asked about the selling price, but did not immediately get a response from business people, or even did not get a response at all. Referring to a statement stating that "women are more likely to be active on Instagram as opposed to men" [13], business people should start actively responding to comments by answering questions or just saying thank you as a form of appreciation. Especially if the one who asks is a woman. Because, in addition to being more active in social media through Instagram, women are also more potential buyers than men for fashion products, including batik.

In some photo posts, it is known that not all photos have a caption. In fact, when sharing photos, users can add the photo caption [14], because, even though an image is considered capable of representing a number of words, in the business world, the addition of caption as a complement to an image can provide a more comprehensive explanation to prospective customers. Likewise with the Hashtag in Caption. When sharing photos, users can add hashtags containing certain words that they want to socialize in the captions on the photos [14]. This facility should be used optimally by the West Java batik business. Because, a number of social media users, often looking for posts using "hashtag-search" [15]. Therefore, when businesses try to promote West Java batik products, at least complete the photos posted with captions and hashtags.

Next is the Influencer / Endorser. In the posting on the account of the West Java batik business, in general, there are not many who use brand influencers or endorsers. If there is one, but the selected endorser is not an independent figure who is a public figure known to the public but only limited to people who are considered to have an appearance that is suitable enough to be a model. This is related to funding problems to hire a public figure who is willing to promote their products, so it is not uncommon for relatives and even business owners who are asked to become endorsers, although they realize that the endorsers they choose do not have good personal popularity in the world real or in cyberspace. although the use of hashtags, the use of celebrities as endorsers, and paid promotions can be adjusted to the targets set by the company [16], it is best that those who are the minimum endorsers are people who are already known by the target public. 
Equally important is the quality and artistic value of photos. There are several photos posted that do not appear to have the quality and artistic value of photos because shooting is more likely to be done by a mobile camera with simple shooting techniques. The thing that must be considered by the company, is that the inclusion of text, images, and impressions should be inspiring so that they are more intriguing than simply displaying brand icons or using direct, promotional phrases. Therefore, marketing through Instagram should be smooth and provide space for the target audience to imagine [14]

There are several opportunities that have escaped optimal utilization by business people in managing social media accounts aimed at promoting and marketing West Java batik, including Postings are sometimes not thematic, have not utilized Quiz and Instastory Voting facilities, have not done links to social media others, and there are still posts that are less relevant to business goals.

In addition, the West Java batik business people also do not have full efforts to make their account as an official account that has the blue check, complete data in Bio Business, and also impression management. The neglect of the facilities provided by various platforms in social media for business interests is not only caused by ignorance, but also by incompetence. Some business people claim to have known the usefulness of several business support features in various social media platforms but have not been able to use them, because there is no human resources personnel specifically asked as managers of social media for promotional and marketing activities. There is an opinion that states: the results of digital marketing will not succeed without hard work, and without trial, and learn from mistakes. The motto "test, learn, and evolve" must be at the heart of all creative ideas in digital marketing. Companies must create innovative experiences for customers, and media strategies to identify the best strategies to improve performance through digital marketing [17].

Therefore, adoption efforts must also consider the internal conditions of the company, including financial conditions. Thus, it is necessary to make alternative efforts by collaborating with educational institutions engaged in information technology and marketing communication media to accept job training students with certain conditions, such as being assigned to manage corporate social media.

In addition, business people can also take part in training in making online media for promotion and marketing, because many batik training sessions have been conducted by private batik companies, batik training centers, and public schools by various institutions. Even the Department of Education, Youth and Sports (DISDIKPORA) or the local Education, Youth, and Sports Agency has approved the batik training policy as extracurricular local content in the recent public school curriculum [18]. This recommendation needs to be tested considering there is a research that states that: There is great potential to do batik business, because batik is a cultural product, which has been rooted from generation to generation, has aesthetic and sacred values, availability of infrastructure and a good market. The obstacles are lack of government support, business run individually, and lack of promotion [19]

This statement was reinforced by suggestions from other research that stated that to improve competitiveness SMEs needed synergistic cooperation between the government, the private sector, and the hard work of MSMEs themselves [20]. Synergistic collaboration can also be done with independent institutions such as the Duta Batik Foundation in West Java which was specifically established to develop batik in West Java.

Another alternative that can be done is to form a batik entrepreneur association and conduct business consultations with consultants hired by the association, because in principle: hiring a skilled analyst in the field of digital marketing analysis is a separate asset for the 
company, however, in an era of increasingly intense business competition, companies are often forced to require business consulting services from a consultant [21]

Therefore, to save budget, leasing consultant services can be done collectively through associations. In addition to the synergistic collaboration between batik business people in West Java, and associations, it is also necessary to create synergistic collaboration with the government. An example is one of the promotional efforts of batik in one of the cities in Yogyakarta, namely Klaten: The Klaten District Government applies the uniform use of civil servants, facilitates the marketing of batik and lurik, establishes tourist villages, organizes batik and lurik carnivals, batik, and lurik design competitions, as well as training in batik making and lurik designs [22]

\section{Conclusion}

Based on the results of the analysis, a number of identifiable problems were obtained, namely: the number of followers is relatively low, the content and packaging of the information posted is still not enough to capture the attention of the target audience, there is no setting up of an account to become an account that can be accessed by the public, the low number of posts, do not post regularly, the limited number of comments which commented on the post, it does not directly respond to potential customers who make comments, not all photos posted are captioned, the lack of use of hashtags, using an influencer or endorser brand that is not well known to the public, photos posted do not have the quality and artistic value of photos, posts are not thematic, not yet using the quiz facility, not yet using the instastory voting facility, not yet linked to other social media, there are still posts that are less relevant to business goals, have not made the account an official account that has blue verification tags, have not filled out the data in the bio business, not yet utilizing impression management facilities.

The cause of the emergence of these problems comes from the lack of understanding and inability of business people to utilize facilities on the Instagram platform. Therefore, it is necessary to collaborate, to make a mutualism symbiosis relationship, comes from a lack of understanding and inability of business people to utilize facilities on the Instagram platform. Therefore, it is necessary to collaborate, to make a mutualism symbiosis relationship, business people can make associations and submit applications to the government through related agencies, to also provide training in social media management as an implementation of synergistic cooperation, so as to create conditions to train together. and both are trained.

\section{References}

[1] J. Pudjowati, "Social Network and Economic Empowerment Strategy to Keep Survival of SMES for Batik ( Study: SMES Batik Mangrove Surabaya )," IOSR J. Econ. Financ., vol. 7, no. 2, pp. 67-70, 2016.

[2] A. Zainal, M. Raden, and M. I. Qeis, "Typography And Local Culture: How Local Values Influence Batik Label Design In Yogyakarta And Surakarta," Int. J. Sci. Technol. Res., vol. 6, no. 08, pp. 108-111, 2017.

[3] M. Pinasti and W. R. Adawiyah, "Co-opetition to promote growth of batik small and medium enterprises,” Int. J. Bus. Soc., vol. 17, no. 3, pp. 401-412, 2016.

[4] B. Y. Durmaz and I. H. Efendioglu, "Travel from Traditional Marketing to Digital Marketing," 
Glob. J. Manag. Bus. Res. E Mark., vol. 16, no. 2, 2016.

[5] F. Ghotbifar, M. R. Marjani, and A. Ramazani, "Identifying and assessing the factors affecting skill gap in digital marketing in communication industry companies," Indep. J. Manag. Prod., vol. 8, no. 1, pp. 1-14, 2017.

[6] I. Fierro, D. Arbelaez, and J. Gavilanez, "Digital marketing: a new tool for international education," Pensam. gestión. Univ. del Norte, vol. 43, pp. 220-240, 2017.

[7] J. Yu and Y. Shen, "Evolutionary personalized hashtag recommendation," Lect. Notes Comput. Sci. (including Subser. Lect. Notes Artif. Intell. Lect. Notes Bioinformatics), vol. 8485 LNCS, no. 61202408, pp. 34-37, 2014.

[8] M. N. Fatanti and I. W. Suyadnya, "Beyond User Gaze: How Instagram Creates Tourism Destination Brand?," Procedia - Soc. Behav. Sci., vol. 211, no. September, pp. 1089-1095, 2015.

[9] S. H. Salojärvi, "Opportunities and challenges of content marketing as a way of digital marketing communications," Bachelor's Thesis. Lappeenranta Univ. Technol., 2016.

[10] L. Pauwels, "A Multimodal Framework for Analyzing Websites," J. Comput. Commun., vol. 17, pp. 247-265, 2012.

[11] A. Sjöberg, C.-J. Rosenbröijer, and B. Oy, "Influencing Brand Awareness Through Social Media Case: BEdesign Oy in Facebook and Instagram," Master's Thesis Int. Bus. Manag., 2017.

[12] L. I. Laestadius and M. M. Wahl, "Mobilizing social media users to become advertisers: Corporate hashtag campaigns as a public health concern," Digit. Heal., vol. 3, p. $205520761771080,2017$.

[13] P. Sheldon and K. Bryant, "Instagram: Motives for its use and relationship to narcissism and contextual age," Comput. Human Behav., vol. 58, pp. 89-97, 2016.

[14] C. Y. Chang, "Visualizing brand personality and personal branding : case analysis on Starbucks and Nike's brand value co-creation on Instagram," MA (Master Arts) thesis, Univ. Iowa, 2014.

[15] S. Müller, E. Simonsson, S. J. Hagberg, and S. Müller, "Working with Social Media in Japan In the case of H \& M , Ikea and Volvo Corporation," Master Degree Proj. Mark. Consum., vol. $109,2015$.

[16] S. Lestari and L. Aldianto, "Effect of using hashtag, celebrity endorsement and paid promote to achieve promotion objective in instagram case study: Women fashion brand," J. Innov. Entrep., vol. 1, no. 1, pp. 1-7, 2016.

[17] A. Yasmin, S. Tasneem, and K. Fatema, "Effectiveness of Digital Marketing in the Challenging Age: An Empirical Study,” Int. J. Manag. Sci. Bus. Adm., vol. 1, no. 5, pp. 69-80, 2015.

[18] P. Nugroho, "The Role of Local Institutions in Industrial Cluster Development in Indonesia: The Cases of Javanese Batik Clusters in Kampung Laweyan, Kampung Kauman and Lasem Area," A Diss. Submitt. to Fac. Spat. Planning, Tech. Univ. Dortmund Partial fulfilment Requir. degree Dr.-Ing. Submitt., 2014.

[19] J. O. Haryanto and S. H. Priyanto, "Recent Future Research In Consumer Behavior: A Better Understanding Of Batik," J. Arts, Sci. Commer., vol. 4, no. 4, pp. 32-40, 2013.

[20] A. Octavia and H. Ali, "The Model of Market Orientation , Entrepreneurial Orientation and Business Performance of Small and Medium Enterprises," Int. Rev. Manag. Mark., vol. 7, no. 3, pp. 331-337, 2017.

[21] P. S. H. Leeflang, P. C. Verhoef, P. Dahlström, and T. Freundt, "Challenges and solutions for marketing in a digital era," Eur. Manag. J., vol. 32, pp. 1-12, 2014.

[22] K. A. Setiyaning and P. Nugroho, "The Role of Batik and Lurik in Forming Local Identity in Klaten Regency Based on Public Perception,” J. Reg. City Plan., vol. 28, no. 1, p. 32, 2017. 